\title{
Organizational Climate and Problems Faced by Rural School Teachers
}

\author{
V.K. Chaithra* and Uma S. Hiremath \\ Department of Extension and Communication Management, College of Community Science, \\ University of Agricultural Sciences, Dharwad-580 005, Karnataka, India \\ *Corresponding author
}

\section{A B S T R A C T}

\section{Keywords}

Rural, Teachers, School, Problems

Article Info

Accepted:

25 May 2018

Available Online:

10 June 2018
Education is perceived to be universal phenomena. It is adequately organized and regulated through formal institutions like schools and colleges. There are different factors, which determine the quality of education and its contribution to national development. The quality competence and character of teacher are undoubtedly very significant. Though India is developing rapidly and many initiatives had been taken for the development of rural India, still much more have to be done. There are several problems being faced by the schools running in rural India so the objective of the study is to study the organizational climate and problems faced by rural school teachers. The study was undertaken in the year 2016-17 in Dharwad and Kalaghatagi taluks of Dharwad district of Karnataka. Total 150 primary and secondary rural school teachers were selected for the study. The data was collected with the help of pre-tested questionnaire. Majority (76.67\%) of the respondents perceived as favourable followed by more favourable (22.67 \%) and less favourable $(0.66$ $\%)$. The major problems faced by rural school teachers are drinking water, lack of teaching aids, no sufficient building for school, family responsibilities, no play ground, less guidance, no toilet rooms, lack of coordination, health problems, unnecessary record enquiry, lack of adjustment difficult to take care of children and lack of freedom for free discussion.

\section{Introduction}

Education is the process by which an individual grows, develops and become increasingly well adjusted in a changing society. Education provides experiences that enable a person from desirable habits, broaden mental vision and deepen understanding of his/her status in the society and acquire skills to meet and solve the problems encountered every day.
Organizational climate is defined as the perceived, subjective effect of the formal system, the informal style and other environmental factors on the attitude, beliefs, values and motivation of people who work in a particular organization (Litwin and Stringer, 1968).

Organizational climate is the formal system of task and reporting relationships that controls, coordinates and motivates employees so that 
they cooperate to achieve an organization's goals. The importance of the organizational climate to teachers' effectiveness is relevant to a high degree, since it is indicative of how well the teacher manages to realize his/her full potential. High-performance organizations tend to make optimal use of everyone's capabilities. Organizational climate definitely affects the teacher's performance in school. It will affect their motivation and dedication at work, job satisfaction and efficacy.

In a developing country like India, the educational system becomes a powerful instrument of economic and social change for accelerating the process of transforming its traditional and agrarian ways and means of living into those of a modern and industrial society. After a period of about two decades of planning, India is still far from obtaining for a large section of its people, the coveted fruits of economic and social equality and there is a growing feeling among concerned people that a large portion of its expanding and developing educational facilities continues to benefit the already privileged strata.

According to Census report, India is the second most populous country in the world, with 121.0 crore people (Anonymous, 2015). Approximately 83.3 crore of India's population lives in rural areas, half of which lies in the age group 6-25 years, the vital age in which a child should be pursuing his/her education to develop himself/herself as a responsible citizen.

Though India is developing rapidly and many initiatives had been taken for the development of rural India, still much more have to be done. There are several problems being faced by the schools running in rural India. Against this background, the study was carried out with the following objectives;

To study the organizational climate of rural school teachers.
To assess the problems faced by rural school teachers.

\section{Materials and Methods}

The study was undertaken in the year 2016-17 in Dharwad district of Karnataka. Dharwad district consists of five talukas viz., Dharwad, Kalaghatagi, Hubli, Navalgunda and Kundgol. Dharwad and Kalghatagi talukas were selected keeping in view the availability of time, the cost and convenience of the researcher. Expost facto research design was followed for conducting the study. List of villages and schools were obtained from the Block Education office of Dharwad district. The villages having more number of schools and schools having more number of teachers were randomly selected. Total 150 primary and secondary rural school teachers were selected for the study.

The questionnaire was pre-tested in non-study area to locate any ambiguity in the questions. After pre-testing certain necessary modifications were made. The finalized questionnaire was used for data collection. Problems were divided into four categories such as problems with basic facilities, with colleagues, with higher officers and at home.

In this study organizational climate was operationalized as the degree to which an individual is committed to organizational goals and objectives. For quantifying this variable the scale developed by Kolb et al. (1974) with slight modification was used. The instrument consisted of eight items involving different dimensions of organizational climate which was rated on a five point continuum namely, strongly agree, agree, undecided, disagree and strongly disagree with 4,3,2,1 and 0 score respectively.

The scoring pattern was reversed for the negative statements. Further the respondents 
were grouped into three categories such as less favourable, fovourable and most favourable.

\section{Results and Discussion}

Organizational climate of rural school teachers about the mentioned statements was measured with the help of five continuums viz., strongly agree, agree, undecided, disagree and strongly disagree.

Table 1 explains the organizational climate of rural school teachers. About one fourth (24.67 $\%)$ of the respondents strongly agreed 'friendliness is a valued norm in the organization'. Three fourth $(74.67 \%)$ of them agreed the 'organization places emphasis on quality and outstanding performance'. Sixty one $(60.67 \%)$ per cent disagreed and 36.67 per cent strongly disagreed to the statement 'there are many rules, procedure, policies and practices rather than work'. Overall index of the organizational climate was 63.91

With respect to the level of perception by rural school teachers on organizational climate (Table 1.1) majority $(76.67 \%)$ of the respondents perceived as favourable followed by more favourable (22.67 \%) and less favourable $(0.66 \%)$. This may be because of the reason that teachers are aware and clear about the goals set by the organization and also there may not be any gender discrimination in providing any type of facilities. Other probable reason might be teachers are friendly, cooperative, support to one another with coordination and good interpersonal relationship between teachers. The results are not in consistent with the study conducted by Rajeev (1998) and Mohan (2000).

The data presented in Table 2 indicates the problems faced with basic facilities. Nearly one third $(32.00 \%)$ of the rural school teachers expressed problem of drinking water followed by lack of teaching aids (27.33\%), no sufficient building for school (24.00\%), no play ground $(21.33 \%)$, no toilet rooms $(20.67$ $\%)$ and lack of transport facilities (19.33\%). Now-a-days everywhere we are finding sever water problem. As the water in wells, bore wells are dried-up, rural schools are finding it difficult to fill the overhead tanks or syntax either for general use or drinking purpose. With respect to teaching aids or supporting materials for teaching, schools might not have received in sufficient quantity. So, also, schools may be facing dearth of funds or grants for expansion of school building as number of students increase. These may be the possible reasons for problems faced by the rural schools teachers. The findings of the study are in line with Akshata (2016).

The data given in Table 3 reveals that lack of coordination $(20.00 \%)$ followed by lack of adjustment (14.67\%), lack of cooperation $(12.00 \%)$ and misunderstanding (7.33\%) were the problems faced with colleagues. The difference in age and experience of the teachers i.e. older age teachers with more years of service might not have showed good cooperation with other colleagues. Due to generation gap there may be less adjustment between older and younger employees. Similar findings were found by Manjula (2000), Kurbett (2012) and Akshata (2016).

It is evident from the Table 4 that 21.33 per cent of them expressed the problem with higher officers as less guidance followed by unnecessary record enquiry $(17.33 \%)$. Other problems were lack of freedom for free discussion (14.00\%), not recognizing prompt teachers $(12.67 \%)$, assigning works other than job chart $(11.33 \%)$ and only concentrating on records not the problems $(6.67 \%)$. It may be due to the busy schedule of head master of their respective schools and other higher officers such as school inspectors and Block Education Officers. Other reason could be 
higher officers may think teachers have clear concept about discharging their duties and responsibilities and no need of guidance. The results are in line with the study conducted by Joshi et al. (2012).

Table.1 Organizational climate as perceived by rural school teachers

$$
\mathbf{n}=\mathbf{1 5 0}
$$

\begin{tabular}{|c|c|c|c|c|c|c|}
\hline $\begin{array}{l}\text { SI. } \\
\text { No }\end{array}$ & Statements & $\begin{array}{l}\text { Strongly } \\
\text { agree } \\
\text { F }\end{array}$ & $\begin{array}{l}\text { Agree } \\
\qquad \text { F }\end{array}$ & $\begin{array}{l}\text { Undecided } \\
\qquad \mathrm{F}\end{array}$ & $\begin{array}{l}\text { Disagree } \\
\text { F }\end{array}$ & $\begin{array}{l}\text { Strongly } \\
\text { disagree } \\
\text { F }\end{array}$ \\
\hline & Do you agree that & & & & & \\
\hline $1^{*}$ & $\begin{array}{l}\text { There are many rules, procedure, } \\
\text { policies and practices to which you } \\
\text { have to confirm rather than being able } \\
\text { to do your work as you see it }\end{array}$ & - & $\begin{array}{c}1 \\
(0.66)\end{array}$ & $\begin{array}{c}3 \\
(2.00)\end{array}$ & $\begin{array}{c}91 \\
(60.67)\end{array}$ & $\begin{array}{c}55 \\
(36.67)\end{array}$ \\
\hline 2 & $\begin{array}{l}\text { You can make decisions and solve } \\
\text { problems without checking with } \\
\text { supervisors each setup of the work }\end{array}$ & $\begin{array}{c}15 \\
(10.00)\end{array}$ & $\begin{array}{c}109 \\
(72.67)\end{array}$ & $\begin{array}{c}15 \\
(10.00)\end{array}$ & $\begin{array}{c}10 \\
(6.67)\end{array}$ & $\begin{array}{c}1 \\
(0.66)\end{array}$ \\
\hline 3 & $\begin{array}{l}\text { The organization places emphasis on } \\
\text { quality performance and outstanding } \\
\text { production including the degree to } \\
\text { which you feel that organization is } \\
\text { setting challenging goals for itself and } \\
\text { communicating these goal } \\
\text { commitment to its members }\end{array}$ & $\begin{array}{c}22 \\
(14.67)\end{array}$ & $\begin{array}{c}112 \\
(74.67)\end{array}$ & $\begin{array}{c}14 \\
(9.33)\end{array}$ & $\begin{array}{c}2 \\
(1.33)\end{array}$ & - \\
\hline 4 & $\begin{array}{l}\text { The organization recognizes and } \\
\text { rewards for the good work of } \\
\text { members rather than being ignored, } \\
\text { critized or punished when something } \\
\text { goes wrong }\end{array}$ & $\begin{array}{c}28 \\
(18.67)\end{array}$ & $\begin{array}{c}90 \\
(60.00)\end{array}$ & $\begin{array}{c}19 \\
(12.67)\end{array}$ & $\begin{array}{c}12 \\
(8.00)\end{array}$ & $\begin{array}{c}1 \\
(0.66)\end{array}$ \\
\hline 5 & $\begin{array}{l}\text { Things are well organized and goals } \\
\text { are clearly defined than being } \\
\text { disordering, confused or chaotic }\end{array}$ & $\begin{array}{c}22 \\
(14.67)\end{array}$ & $\begin{array}{c}83 \\
(55.33)\end{array}$ & $\begin{array}{c}25 \\
(16.67)\end{array}$ & $\begin{array}{c}19 \\
(12.67)\end{array}$ & $\begin{array}{c}1 \\
(0.66)\end{array}$ \\
\hline 6 & $\begin{array}{l}\text { Friendliness is a valued norm in the } \\
\text { organization that you can trust one } \\
\text { another and offer support to one } \\
\text { another }\end{array}$ & $\begin{array}{c}37 \\
(24.67)\end{array}$ & $\begin{array}{c}92 \\
(61.33)\end{array}$ & $\begin{array}{c}16 \\
(10.67)\end{array}$ & $\begin{array}{c}4 \\
(2.67)\end{array}$ & $\begin{array}{c}1 \\
(0.66)\end{array}$ \\
\hline 7 & $\begin{array}{l}\text { As needs for leadership arise } \\
\text { members feel free to take leadership } \\
\text { roles and are rewarded for successful } \\
\text { leadership }\end{array}$ & $\begin{array}{c}34 \\
(22.67)\end{array}$ & $\begin{array}{c}88 \\
(58.67)\end{array}$ & $\begin{array}{c}21 \\
(14.00)\end{array}$ & $\begin{array}{c}7 \\
(4.66)\end{array}$ & - \\
\hline 8* & $\begin{array}{l}\text { Any gender discrimination in } \\
\text { providing facilities }\end{array}$ & $\begin{array}{c}10 \\
(6.67)\end{array}$ & $\begin{array}{c}74 \\
(49.33)\end{array}$ & $\begin{array}{c}25 \\
(16.67)\end{array}$ & $\begin{array}{c}26 \\
(17.33)\end{array}$ & $\begin{array}{c}15 \\
(10.00)\end{array}$ \\
\hline \multicolumn{6}{|c|}{ Overall organizational climate Index } & 63.91 \\
\hline
\end{tabular}

Note: * Indicates negative statements

Figures in the parentheses indicate percentage 
Table.1 Level of perception by rural school teachers on organizational climate

\begin{tabular}{|l|c|c|}
\hline Categories & Frequency & Percentage \\
\hline Less favourable & 1 & 0.66 \\
\hline Favourable & 115 & 76.67 \\
\hline More favourable & 34 & 22.67 \\
\hline
\end{tabular}

Table.2 Problems faced by rural school teachers with basic facilities

\begin{tabular}{|c|c|c|c|}
\hline Sl. No. & Problems & Frequency & Percentage \\
\hline 1 & Lack of drinking water facility & 48 & 32.00 \\
\hline 2 & No school compound & 19 & 12.67 \\
\hline 3 & Lack of water facility & 27 & 18.00 \\
\hline 4 & No play ground & 32 & 21.33 \\
\hline 5 & No toilet rooms & 31 & 20.67 \\
\hline 6 & No sufficient building for school & 36 & 24.00 \\
\hline 7 & Lack of transport facility & 29 & 19.33 \\
\hline 8 & No computer facility & 15 & 10.00 \\
\hline 9 & Lack of teaching aids & 41 & 27.33 \\
\hline 10 & No library & 13 & 8.67 \\
\hline 11 & Inadequate sports materials & 22 & 14.67 \\
\hline 12 & Lack of furniture & 24 & 16.00 \\
\hline
\end{tabular}

Table.3 Problems faced by rural school teachers with colleagues

$\mathbf{n}=\mathbf{1 5 0}$

\begin{tabular}{|c|l|c|c|}
\hline Sl. No. & Problems & Frequency & Percentage \\
\hline $\mathbf{1}$ & Lack of cooperation & 18 & 12.00 \\
\hline $\mathbf{2}$ & Lack of coordination & 30 & 20.00 \\
\hline $\mathbf{3}$ & Lack of adjustment & 22 & 14.67 \\
\hline $\mathbf{4}$ & Misunderstanding & 11 & 7.33 \\
\hline
\end{tabular}


Table.4 Problems faced by rural school teachers with higher officers

$\mathbf{n}=\mathbf{1 5 0}$

\begin{tabular}{|c|l|c|c|}
\hline Sl. No. & \multicolumn{1}{|c|}{ Problems } & Frequency & Percentage \\
\hline $\mathbf{1}$ & Less guidance & 32 & 21.33 \\
\hline $\mathbf{2}$ & Unnecessary record enquiry & 26 & 17.33 \\
\hline $\mathbf{3}$ & Assigning works other than job chart & 17 & 11.33 \\
\hline $\mathbf{4}$ & Lack of freedom for free discussion & 21 & 14.00 \\
\hline $\mathbf{5}$ & Not recognising prompt teachers & 19 & 12.67 \\
\hline $\mathbf{6}$ & $\begin{array}{l}\text { Only concentrating on records not } \\
\text { the problems }\end{array}$ & 10 & 6.67 \\
\hline
\end{tabular}

Table.5 Problems faced by rural school teachers at home

\begin{tabular}{|c|l|c|c|}
\hline Sl. No. & \multicolumn{1}{|c}{ Problems } & Frequency & Percentage \\
\hline $\mathbf{1}$ & Health problems & 27 & 18.00 \\
\hline $\mathbf{2}$ & Difficult to take care of children & 22 & 14.67 \\
\hline $\mathbf{3}$ & No family support & 15 & 10.00 \\
\hline $\mathbf{4}$ & Family responsibilities & 35 & 23.33 \\
\hline $\mathbf{5}$ & Travelling for long distance & 16 & 10.67 \\
\hline
\end{tabular}

A close look at Table 5 indicates that Problems faced by the respondents at home were family responsibilities $(23.33 \%)$ followed by health problems $(18.00 \%)$, difficult to take care of children $(14.67 \%)$, travelling for long distance $(10.67 \%)$ and no family support $(10.00 \%)$. Female teachers have to face dual role one in job and another in taking care of family members and children wherein, she needs cooperation and proper understanding of family members. Family support is very much essential to perform the job satisfactorily. This finding was in conformity with the findings of Kurbett (2012).

On the basis of the findings of the study, it is concluded that lack of drinking water facility, lack of teaching aids, no sufficient building for school, no play ground, no toilet rooms, less guidance, unnecessary record enquiry, lack of coordination, lack of transport facilities, health problems and family responsibilities were the problems expressed by the rural school teachers. Of the problems faced infrastructure and other related issues need to be addressed by the government. In order to solve other problems with colleagues, higher officers and family, the teachers need to attend refresher courses, personality development trainings and such others to keep them motivated and performing their jobs effectively.

\section{References}

Akshata, R., 2016, Training need identification and job satisfaction of subject matter specialists of Krishi Vigyan Kendras in Karnataka. M. $H$. 
Sc. Thesis, Univ. Agric. Sci., Dharwad (India).

Anonymous, 2015, Malayalam Manorama Year book, Kochi, pp. 668-670.

Joshi, P., Vidya, V. T. and Wattamwar, V. M., 2012, Constraints faced by anganwadi workers in communication of information. Agriculture Update, 7 (3):

Kolb, D. A., Rubin, I. M. and Mctntyre, J. M., 1974, Organizational Psychology (2nd Ed.), Prentice Hall Inc., New Jersey, pp. 39-64.

Kurbett, P. Y., 2012, Job involvement and job satisfaction of women officers of Karnataka state. M. H. Sc. Thesis, Univ. Agric. Sci., Dharwad (India). 279-282.
Litwin, G. and Stringer, R., 1968, Motivation and Organizational Climate, Harward University Press, Boston, pp. 19-33.

Manjula, N., 2000, A study on job perception, job performance and job satisfaction of AAO (FW) in Karnataka. M. Sc. (Agri.) Thesis, Uni. Agric. Sci., Bangalore (India).

Mohan. B., 2000, A study on job performance and job satisfaction of assistant agricultural officers in northern district of Karnataka. M. Sc. (Agri.) Thesis, Univ. Agric. Sci., Dharwad (India).

Rajeev, P., 1998, A study on perception of organizational climate and job satisfaction of agricultural scientists in KAU. M. Sc. (Agri.) Thesis, Univ. Agric. Sci., Bangalore (India).

\section{How to cite this article:}

Chaithra, V.K. and Uma S. Hiremath. 2018. Organizational Climate and Problems Faced by Rural School Teachers. Int.J.Curr.Microbiol.App.Sci. 7(06): 3566-3572. doi: https://doi.org/10.20546/ijcmas.2018.706.419 